\title{
THE ROLE OF PUBLIC SPHERE ACCORDING TO JURGEN HABERMAS'S PERSPECTIVE FOR MULTICULTURAL SOCIETIES IN THE INDONESIAN CONTEXT
}

\author{
Engki Prasutomo \\ Sekolab Tinggi Filsafat Theologia Jaffray Makassar,engkiprasutomo.sttj15@gmail.com \\ Hengki Wijaya \\ Sekolah Tinggi Filsafat Theologia Jaffray Makassar, hengkinijaya@sttjaffray.ac.id \\ Ivan Th. J. Weismann \\ Sekolah Tinggi Filsafat Theologia Jaffray Makassar, ivanweismann@yahoo.com
}

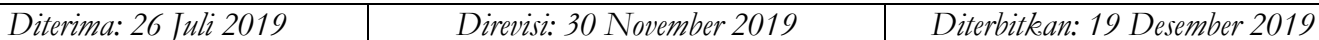

\begin{abstract}
This paper explains the role of the public sphere based on Jurgen Habermas's concept and analyzes its relevance for multicultural societies in the Indonesian Context. The public sphere exists to present democracy, tolerance, friendship, inclusivism in diversity, unity in diversity, and education. Indonesia is a country that reflects multiculturalism, can realize peace and unity within a multicultural frame. This article was developed using the Systematic Literature Review (SLR) method. This paper explains the role of public space based on Jurgen Habermas for interdisciplinary scholarship and its relevance. Its findings show Jurgen Habermas's approach through the public sphere can bring about unity and peace in all aspects of life, including differences in beliefs and multicultural contexts.
\end{abstract}

Keywords: public sphere, multicultural, Jurgen Habermas, religion.

\begin{abstract}
Abstrak
Tulisan ini menjelaskan peran ruang publik berdasarkan konsep Jurgen Habermas dan relevansinya untuk masyarakat multikultural dalam Konteks Indonesia. Ruang publik ada untuk menghadirkan demokrasi, toleransi, persahabatan, inklusivisme dalam keragaman, persatuan dalam keragaman, dan dalam pendidikan. Indonesia adalah negara yang mencerminkan multikulturalisme, dapat mewujudkan perdamaian dan persatuan dalam kerangka multikultural. Artikel ini disusun dengan menggunakan metode Systematic Literature Review (SLR). Tulisan ini menjelaskan peranan ruang publik berdasarkan Jurgen Habermas bagi interdisipliner keilmuan, dan relevansinya. Temuannya menunjukkan pendekatan Jurgen Habermas melalui ruang publik dapat mewujudkan persatuan, dan perdamaian dalam segala aspek kehidupan termasuk perbedaan keyakinan dan konteks multikultural.
\end{abstract}

Kata Kunci: ruang publik, multikultural, Jurgen Habermas, agama. 


\section{INTRODUCTION}

Humans are multidimensional and complex creatures of God. Humans cannot be separated from one another, so humans are not only said to be multifaceted creatures of God and are complex, but humans are social creatures. Humans as social creatures that live in the community system. Life in a community system provides lessons for living together.

Living together in a community system has many challenges because in a society composed of multicultural groups. An organization is said to be multicultural if it has diversity and diversity. ${ }^{1}$ In a multicultural society, each group has different customs, ideals, and life values. What often happens is that each group tends to consider its group entitled to an absolute truth claim. Thus, if you do not want this to happen in a multicultural community, open communication is needed. Because of its substantial role, many scholars have formulated normative theories that describe how to interface must be structured to fulfill this role ideally. ${ }^{2}$ One of the communication figures who paid great attention to the problems of multicultural societies was Jürgen Habermas.

Through communication, Habermas develops the concept of the rationality of shared life. His monumental work entitled The Theory of Communicative Action (1984 and 1987), published in two volumes. Rational dialogue is one of the essential bases for realizing peaceful coexistence between people and all their diverse backgrounds. So Jürgen Habermas defines it as ethical discourse. Discourse ethics refers more to procedural ethics, namely the principle of universalizing the moral norms as in Kant. Because according to Hermas, the validity of a moral rule cannot be determined through

\footnotetext{
${ }^{1}$ Ketut Gunawan and Yohanes Rante, "Manajemen Konflik Atasi Dampak Masyarakat Multikultural Di Indonesia," Jurnal Mitra Ekonomi Dan Manajemen Bisnis 2, no. 2 (2011): 212-24.

2 Myra Marx Ferree et al., "Four Models of the Public Sphere in Modern Democracies," Theory and Society 31, no. 3 (2002): 289-324.
}

individual reflections of individuals but is more ethical and rational if done together through a discourse. $^{3}$

Discourse ethics initiated by Jurgen Habermas focuses on the creation of the public sphere in the community system. Today, the public sphere is significant for modern society. The public sphere functions is a forum in which to communicate relevant issues collectively. And allows citizens to inform themselves about community development. Habermas believes that discourse can break down the walls of ethnocentrism and expand the horizon of solidarity to the universal value of humanity. ${ }^{4}$

Indonesia is known as a democratic country. Deliberation and consensus is a traditional decision-making regulation in Indonesia that has been regulated in legislation. This regulation makes these laws and regulations still apply today in Indonesia and are not included in discussions abroad, but also outside the debate. ${ }^{5}$ The public sphere initiated by Habermas has similarities with the values of consensus in Indonesia. Through this paper, we connect the benefits of national character and culture with the role of the public sphere in the diversity of the nation but still one unity. The purpose of this paper is to explain the part of the public sphere based on Jurgen Habermas's perspective for the multicultural community in the Indonesian Context.

3 Dominique Rio Adiwijaya, "Perbandingan antara Etika Jürgen Habermas dan Richard Rorty sebagai Prinsip Dasar Bertindak Manusia," Humaniora 1, no. 2 (October 30, 2010): 205-12, https://doi.org/10.21512/humaniora.v1i2.2862.

4 Supar Supartiningsih, "Etika Diskursus Bagi Masyarakat Multikultural: Sebuah Analisis dalam Perspektif Pemikiran Jürgen Habermas," Jurnal Filsafat 17, no. 1 (March 22, 2017): 32-59, https://doi.org/10.22146/jf.23231.

${ }^{5}$ Koichi Kawamura, "Consensus and Democracy in Indonesia: Musyawarah-Mufakat Revisited," SSRN Electronic Journal, 2011, https://doi.org/10.2139/ssrn.2280935. 


\section{THEORETICAL FRAMEWORK}

\section{A. Jurgen Habermas's Public Sphere Concept}

The concept of the public sphere, according to Jurgen Habermas, is divided into three parts. First, the explanation of the understanding of the idea of the public sphere with various meanings on it that emerges through multiple perspectives and scientific disciplines. Second, Habermas's interpretation of the bourgeois public sphere, as written in the book The Structural Transformation of the Public Sphere. Third, the concept of the public sphere in a deliberative democratic framework that appears in the text Between Facts and Norms. ${ }^{6}$

In the first, the meaning of the public sphere. Namely social capital, public services, public goods, open culture, public places, and interrelation between markets, families, governments, and independent groups that shape the sociality of society. ${ }^{7}$

In the second part, Habermas is more related to the public sphere with conditions that allow citizens (private sphere) to come together to articulate their interests to form opinions and will together in a discursive manner. The bourgeois public sphere is understood as the sphere of private people who gather as public. ${ }^{8}$

There are two main themes proposed by Habermas in The Structural Transformation of Public Sphere, namely, first, his analysis of the origin of bourgeois public sphere; second, structural changes in public sphere in modern times marked by the rise of capitalism, the culture industry, and the increasingly strong position of organizations engaged in the economy and large business groups in public life. ${ }^{9}$

6 Antonius Galih Prasetyo, "Menuju Demokrasi Rasional: Melacak Pemikiran Jürgen Habermas Tentang Ruang Publik," Jurnal Ilmu Sosial Dan Ilmu Politik 16, no. 2 (2012): 169-84.

7 Prasetyo.

8 Jürgen Habermas, The Structural Transformation of the Public Sphere: An Inquiry into a Category of Bourgeois Society, 10. print, Studies in Contemporary German Social Thought (Cambridge, Mass: MIT Press, 1999).

${ }^{9}$ Habermas.
Habermas divides the public sphere into two types; (1) political public spheres, and (2) literary public spheres. The governmental public sphere not only shows the openness of the accessible sphere but also shows how the social structure of society changes. The social classes formed by the feudal system can no longer be sustained. Meanwhile, in the public sphere of literature, awareness of general literacy began to increase in line with the emergence of publications, general discussions about art, aesthetics, and research spread throughout Europe. $^{10}$

The bourgeois public sphere arose when civil society (the bourgeoisie) began to file claims against the state's global demands, which were formulated in the form of questions about whether the state had served the public interest. The bourgeois public sphere is thus the sphere of private people who gather together as the public. The country is invited to debate on issues that are private but have general relevance, such as the issue of commodity exchange and social work. ${ }^{11}$

The public sphere is rooted and compacted in civil society institutions. Civil society is different from the bourgeoisie so that the public sphere it lives in is comparatively more inclusive and does not hold an ideological blanket than the bourgeois public sphere. In the landscape of social totality, civil society must be distinguished from the state and market, and, although related to the private field, must also be separated from it. ${ }^{12}$

The bourgeois public sphere holds the normative ideals of the Enlightenment inheritance, which are implicitly contained in it: freedom, solidarity, equality. In it, an interpretation of the common good is carried out, which in turn becomes the criterion for testing

\footnotetext{
${ }^{10}$ Habermas.

11 Habermas.

12 Jürgen Habermas and William Rehg, Between Facts and Norms: Contributions to a Discourse Theory of Law and Democracy, 1 MIT Press paperback ed., 4. printing, Studies in Contemporary German Social Thought (Cambridge, Mass.: MIT Press, 2001).
} 
the plausibility of the claims submitted by its members. ${ }^{13}$

In the third part, the concept of the public sphere, Habermas stressed the importance of the general area in the Context of the theory of discourse on law and democracy. This turn around to the public sphere is not intended to romanticize a break from contemporary reality. But rather as a project or task of mobilizing the communicative flow that already exists between social practices and institutional structures in a liberal democratic system. ${ }^{14}$ Habermas gives his recognition of the plurality of public spheres. It is a recognition that arises from reflection on the increasingly complex and plural empirical conditions of contemporary modern society. Each community and group can form its public sphere. $^{15}$

\section{B. Functions of Public Spheres}

Habermas said that three normative ideals are inherent in the concept of the public sphere. ${ }^{16}$ First, the public sphere is a kind of social interaction which in no way, assumes equality of status between people because the concept of the situation in the public sphere itself is seen to have no significance whatsoever. In the public sphere, the thing that occupies a higher place than the others is not status, rank, wealth, or descent, but a better argument. Second, although everyone has different interests that may be influenced by differences in status, one's interests are also seen as having no significance. What unites people who meet in the public sphere is the similarity in the use of ratios that are characterized by "disinterested" interest of reason. That is, the justification for arguments that arise in the public sphere must be based on the public interest and not the particular interests. Third, the public

13 Prasetyo, "Menuju Demokrasi Rasional: Melacak Pemikiran Jürgen Habermas Tentang Ruang Publik."

14 Prasetyo.

15 Prasetyo.

${ }^{16}$ Habermas, The Structural Transformation of the Public Sphere. sphere is, in principle, inclusive. This inclusiveness is reflected in the strict formality of the requirements for being able to participate in the public sphere, that is, every member of humanity who can use his rationality. ${ }^{17}$ An inclusive public sphere functions to unite different thoughts for the common interest over the interests of groups and communities.

\section{Criteria of the Public Sphere}

Habermas has three standards as the public sphere of society. First, they put aside the differences in social status and bring up the principles of togetherness and equality as the spirit of each meeting between them. Social stratification that places the merchants as a middle class (bourgeois) society begins to change. Visitors who come to the coffee shops do not only come from the bourgeoisie, but employees, shop owners, as well as professionals and other people gather. The term bourgeoisie then extends not only to merchants. The new stratum of bourgeois society was born and soon occupied a central position in public. ${ }^{18}$ Every individual who comes to the public sphere is allowed to have an opinion on issues concerning the private or public area. In this condition, the public sphere has the primary role as a driver for the communication ability of each level of society. Therefore, public political spheres and literary public spheres held in these coffee shops are the first places of communication free from the pressure of power.

Second, the public sphere opens up discourses that have never been questioned, such as state and church monopolies on the interpretation of truth in the text. New social forces in society began to bring the literary public sphere into the political realm. Works such as poetry, novels, short stories, music, and theater began to be used as tools for resistance to

\footnotetext{
17 Prasetyo, "Menuju Demokrasi Rasional: Melacak Pemikiran Jürgen Habermas Tentang Ruang Publik."

${ }^{18}$ Habermas, The Structural Transformation of the Public Sphere.
} 
absolute state authority. Likewise, journals produced from public spheres of literature began to criticize aggressively. According to Habermas, art and cultural criticism journals were impressive works in the 18th century as instruments that traditional literary criticism. Even in the political public sphere, the abolition of censorship in England around 1694-1659 was seen as advancing the development of the public sphere. The construction of journals, pamphlets, and the press in the political public sphere began to show its prospects as an independent institution. Call it Diskurse der Mahlern, a weekly journal published by Bodmer and Breitinger in Zurich in 1721 that emerged from the results of meetings in coffee shops. With the increasing communication and critical power of the people, the government cannot face society authoritatively. ${ }^{19}$ The crucial debate in the political sphere (Government and society) places the opposition press as a "fourth force" to carry out their duties as public authorities. The term "fourth power" or "the fourth estate" in every journalism literature is now interpreted as a balancing force of three other troops, namely: executive, legislative, and judicative.

Third, individual meetings in public literature have transformed culture into commodities. The culture referred to by Habermas is written culture (journals and pamphlets), music, and theater culture. Music and theater in the 18th century are still regarded as something elite, glamorous, and can only be enjoyed by aristocrats. For Habermas, what we now call classical music, it used to have a social function, both as sacredness and dignity of worship and lively banquet. Therefore, there is no access for the public to music and theater. But as a result of the advancement of the public literary sphere, gradually, the entrance is increasingly open, even the community creates music and theater independently. ${ }^{20}$ In 1766 , for example, in

\footnotetext{
${ }^{19}$ Habermas.

${ }^{20}$ Habermas.
}

Germany, the Deutsches Nationaltheater (German National Theater) was established that could be accessed by a general audience, so Collegia Musica emerged as the first "public music" in Germany, where entry tickets had to be paid to convert music performance into commodities. ${ }^{21}$

\section{Public Spheres for Multicultural Communities}

In multiculturalism, a society - including Indonesia - is seen as having a culture that is generally accepted in the organization concerned. Such patterns, such as the multiculturalism mosaic model, have been used as a reference for the founding fathers of the Indonesian people in designing what is called the nation's culture. It was revealed in the explanation of article 32 of the 1945 Constitution: "the culture of the nation (Indonesia) is the culmination of regional culture."22

In general, in a challenge in the life of the public, there are three stages of the public sphere, namely: First, 'public spheres encounter,' is the most common public sphere. This public sphere consists of daily communication between citizens. This type of public sphere is the occurrence of communication in people's everyday lives. The public sphere of the meeting does not have a fixed organizational structure and gives citizens many opportunities to discuss a variety of very diverse issues. The impact on society is still rather weak, and the number of people reached is relatively small.

The second forum is 'public events,' including meetings that are held officially. This public sphere often occurs in discussions in various public places, or public speaking in a democratic manner. They at least have a minimal organizational structure, and specialists and opinion leaders participate in this forum and can structure and dominate communication. Public

${ }^{21}$ Jürgen Habermas, "Three Normative Models of Democracy," Constellations 1, no. 1 (December 1994): 1-10, https://doi.org/10.1111/j.1467-8675.1994.tb00001.x.

22 Supartiningsih, "ETIKA DISKURSUS BAGI MASYARAKAT MULTIKULTURAL." 
events have a more significant impact on society and reach more people than 'meeting communication types of public spheres.'

Mass media is the third forum in the public sphere. They have a complete technical and organizational infrastructure. They are dominated by specialists such as journalists, experts, and collective actors, while ordinary citizens are usually connected passively to the recipient's role. In turn, the mass media has a significant impact on society because this forum reaches very broadly and organizes essential parts of community self-observation and the formation of opinions that are in the life of a community.

A multicultural society is a complex society that is holistic. There are three types of multiculturalism regimes. First, a multiculturalism regime that adheres to an assimilationist strategy. This type of government seeks to make the diversity that exists in society, melt into one entity. Usually, the majority are adopted. For this regime, differences are only superficial phenomena. The ultimate goal is to eradicate multiculturalism itself. ${ }^{23}$

The second type of regime is a communitarian regime. This regime is the opposite of the first. Communitarians believe that each individual or group of people have different customs, ideals, and values for life that cannot be united. Therefore, he must be given leeway to practice and realize his life's ideals. ${ }^{24}$

The third regime tries to find a balance between the two. The search for balance is guided by philosophical primacy embraced by a multicultural system. This third type of multiculturalism regime seems to be in harmony with Habermas's thinking about the ethics of discourse. Through discourse, on the one hand, Habermas wants to give "insight into social solidarity" to individualism; and on the other hand, he wants to provide "cosmopolitan insight" to collectivism. ${ }^{25}$

\footnotetext{
${ }^{23}$ Supartiningsih.

24 Supartiningsih.

25 Supartiningsih.
}

\section{METHOD}

This article was developed using the Systematic Literature Review (SLR) method $^{26}$ to examine the idea of the role of publich sphere for multicultural society in Indonesian context. For example, the main data of this study is absed on Habermas's works, especially The Structural Transformation of the Public Sphere: An Inquiry into a Category of Bourgeois Society and Between Facts and Norms: Contributions to a Discourse Theory of Law and Democracy. Moreover, this study also makes use of other sources that deal with Habermas. For example, from other books and journal. The Role of the Public Sphere, according to Jurgen Habermas's perspective for multicultural societies in the Indonesian Context. Public sphere theories, according to Jurgen Habermas, are elaborated in this paper to see the role of the public sphere in culturally diverse societies in the Indonesian Context. This paper is explained following qualitatively relevant theories and argumentative results in several published journals. ${ }^{27}$

\section{THE RELEVANCE OF HABERMAS THEORY OF PUBLIC SPHERE FOR MULTICULTURAL SOCIETY IN INDONESIAN CONTEXT}

This discussion explains Habermas's theory of public space in various aspects such as religion, democracy, tolerance, politics, culture, and education. The explanation begins with the role of the public sphere in every aspect. Next, it explains its relevance to a multicultural society and the Indonesian context.

${ }^{26}$ Ester van Laar et al., "The Relation between 21 stCentury Skills and Digital Skills: A Systematic Literature Review," Computers in Human Behavior 72 (July 2017): 57788, https://doi.org/10.1016/j.chb.2017.03.010.

27 Helaluddin Helaluddin and Hengki Wijaya, Analisis Data Kualitatif: Sebuah Tinjanan Teori \& Praktik (Makassar: Sekolah Tinggi Theologia Jaffray Makassar, 2019). 
A. The Role of the Public Sphere in Religion and Democracy

Habermas does recognize that democratic rule of law or secular ratios has religious roots, but that does not mean that the basis of the democratic rule of law must return to religion. In discussion with Cardinal Raztinger, which took place at Katholiche Akademie München, Germany on January 19, 2004, Habermas explored and responded critically to the religious roots of secular ratios in a text frame titled "Prepolitical Foundations of the Constitutional State?" Which was later recorded in Between Naturalism and Religion. ${ }^{28}$

Habermas put forward some of his points. First, the secular state does not base itself on certain cosmological presuppositions as natural law presupposes. The consequence is that a secular state does not favor a particular religious group with its entire value system, and each citizen has equality in playing its role in a democratic rule of law. ${ }^{29}$ Habermas said that it is the democratic process that forms the bond that unites citizens. The method of democracy becomes a condition for the possibility of citizens to fight for their interests. Of course, the freedom intended by Habermas is deliberative democracy, which refers to procedural ratios and is driven by communicative ratios. The communicative rate of citizens moves them to unite themselves in the state freely and without pressure, through deliberative democracy. Second, although from a cognitive perspective and the motivation of the democratic rule of law countries can be sufficient internally, there are external factors that damage the network of citizens' solidarity and democratic processes, namely the market ratio has a different way of working with the state ratio. Markets have different management methods than state administrations. Market ratios lead citizens into individuals who use their freedom strictly. At the

28 Jürgen Habermas, Between Naturalism and Religion: Philosophical Essays (Cambridge, UK; Malden, MA: Polity Press, 2008).

${ }^{29}$ Habermas. same time, the fields under the authority of the democratic rule of law to regulate them are increasingly reduced. Citizens' privatism is getting stronger; the citizens' democratic process is getting weaker. ${ }^{30}$

Habermas called this phenomenon a distortion of modernization. Under these conditions, a democratic rule of law legitimizes itself with legal instruments made by citizens. The main idea in the second point was already stated by Habermas when he reviewed the problem of world life (Lebenswelt) and the system. If, in his description of the world of life and network, Habermas said that the system, namely the market and the state, colonize the realm of experience, today, the market ratio as a system colonizes the life-world and the country at the same time. In a situation of market ratio colonization, which is a form of deviation from modernity. ${ }^{31}$

Habermas said that citizens must overcome this by maximizing the communicative ratio through the mechanism of procedural rates in deliberative democracy to obtain mutual agreement. That is what Habermas calls communicative action. Third, answering doubts raised by Bökenförde that whether the rule of law can provide itself with normative principles in itself, Habermas said that from a cognitive perspective, the positive code still needs a religious and metaphysical view to cognitively ascertain legal policies in the state constitutional law. ${ }^{32}$

Restricted groups are usually more inclined to accept norm decisions made by groups who feel secure, without the public sphere being provided. They tend to allow other stronger groups to make decisions that are in the public sphere and see it as a natural thing to happen. This attitude tends to arise due to an authoritarian religious or social ideology. So that in reality, the weak individual or group readily accepts the

\footnotetext{
${ }^{30}$ Habermas.

${ }^{31}$ Habermas.

32 Habermas.
} 
situation and sees it as a natural and even justified part of the social order. This explanation of passivity at least assumes the fatalistic acceptance of the social order and perhaps even actively participates in what Marxists say "mystification" or "false consciousness" 33 .

In the context of multicultural society, like Indonesia, the public sphere exists in various forms, both in the form of organizations, communities, social media, WhatsApp groups. The presence of the public sphere, both closed and open to diversity and diversity, exists in the Indonesian Context. Over time, the two of them met in a heated democracy struggle. But the public sphere that accepts differences and diversity emerges on the surface with one aim to defend Indonesian nationality. Individually they do not openly reject diversity, but in communities or public spheres express hatred for variety. The actions which were used as a collection of volumes of demonstrations showed that they were brave in the broader community. Interestingly, those who join the public sphere are often unaware of the topics discussed and the aims of their movements on behalf of the people's voices.

\section{B. The Role of the Public Sphere in Politics}

At Habermas, the public sphere in his writings is a public sphere that is examined from a political perspective. Apart from Habermas, many contemporary thinkers theorize about the public sphere in a political view. ${ }^{34}$

The public sphere includes political information providers and debates such as newspapers, journals, political discussion institutions such as parliament, civic clubs, literary clubs, public associations, coffee houses and coffee shops, town halls, and other public places that become spheres for social, political

33 Ivan Th. J Weismann, "Naturalisasi Perbudakan Sebagai Suatu Keadilan,” Jurnal Jaffray 1, no. 1 (January 5, 2005): 29, https://doi.org/10.25278/ji71.v1i1.166.

34 Prasetyo, "Menuju Demokrasi Rasional: Melacak Pemikiran Jürgen Habermas Tentang Ruang Publik.” discussion. In these places, freedom of speech, assembly, and participation in political debates is highly valued..$^{35}$

Political life is unpredictable. Opponents or friends are seen in various public spheres. Whoever wins the chance to lead, some losers in the competition affect the sustainability of existing public spheres. In politics, there is a political agreement that is also reached in the public sphere. There is a good and right agreement; on the contrary, there is an agreement that only prioritizes the interests of the groups. The function of the public sphere is to limit the growth of negative politics. During this time lies lie and quickly enter the public sphere. Then the public sphere continues to the public sphere, which has the same vision. For this reason, the public sphere is needed that can put a halt to the movement of the public sphere dominated by group interests that do not emphasize positive multiculturalism.

The political system functions ideally when formal politics smoothly absorb input from informal politics. The longevity between the two is guaranteed, for example, through the right of political parties (legal, political representation) to "collaborate" in the formation of the political will of society, as well as the reason (active or passive) of citizens to own and other participatory rights ${ }^{36}$ It means that in the political atmosphere, God was also present and, as a nation, became a peaceful family.

This attitude of learning certainly demands appropriate politics and is fair to the fact of cultural pluralism. ${ }^{37}$ Politics exists in the public sphere to bring prosperity to humanity. Politics exists to bring freedom to justice and not

35 Irfan Noor, "Identitas Agama, Ruang Publik Dan Post-Sekularisme: Perspektif Diskursus Jurgen Habermas," Ilmu Ushuluddin 11, no. 1 (2012): 61-87.

36 Habermas and Rehg, Between Facts and Norms.

37 Paulus Eko Kristianto and Hengki Wijaya, "Tilikan Politik Dan Hak Asasi Manusia Di Era Globalisasi," preprint (Open Science Framework, November 5, 2019), https://doi.org/10.31219/osf.io/u5rg7. 
violence perpetrated by religious persons who abuse their theological teachings.

In Christianity, the political attitude of Christians is that the church must not forget the task of calling to preach the good news to the world, and to present God in every time and place in this different life. ${ }^{38}$ This is also done by other religions.

Its relevance in political life in Indonesia should use the public sphere to determine joint decisions for Indonesia's better goals. Political public sphere prevents black campaigns that violate the constitution and respect each other's differences of opinion and talk in a family atmosphere and deliberations.

If the public sphere of politics becomes like a family, Indonesia's political atmosphere will provide coolness and peace amid diversity, diversity, and multiculturalism. The representatives of the people convened by determining decisions that made the people prosperous above personal and group interests.

\section{The Role of the Public Sphere in Religion and Tolerance}

Relevant research on Islamic arguments, the public sphere, and religious harmony can be one alternative social evidence amidst the intricate complexity of ethical issues. ${ }^{39}$

The concept of hospitality as part of individual constructive behavior can be conveyed. According to Al-Mawardi, regarding the analysis of human virtues such as humility, good manners, simplicity, self-control, trust, and freedom from envy and social good, such as good speech,

${ }^{38}$ Fajar Gumelar and Hengki Wijaya, "Peran Gereja Masa Kini Menyikapi Teologi Pembebasan Gutiérrez," BLA': Jurnal Teologi Dan Pendidikan Kristen Kontekstual 2, no. 1 (June 24, 2019): 14-26, https://doi.org/10.34307/b.v2i1.69.

39 Roma Ulinnuha, "Islam, Ruang Publik Dan Kerukunan Antar Umat Beragama (Studi Tradisi Ngebag Kolaboratif Di Karangjati Wetan)," Jurnal Sosiologi Agama 9, no. 2 (March 17, 2017): 29, https://doi.org/10.14421/jsa.2015.092-02. maintaining trust, and speed. In the extended conception of moral excellence. ${ }^{40}$

Regarding tolerance values in Islam for the public sphere clauses, this study notes the element of glorifying guests, alms, and hospitality. These three elements in this study can be found in the narrative of the citizens related to the traditional process and its implementation. In the praxis dimension, village ancestors incorporate elements of the valuable teachings not verbally but instead utilize the aspects of traditional practices as their medium. ${ }^{41}$ In the dialogue between religions, it must be emphasized that tolerance and inclusiveness, for example, in Christianity and Islam, there are similarities as the beginning of an inclusive dialogue. ${ }^{42}$

The neutrality of the public sphere does not mean the empty sphere of religion. In the name of democracy, the position of faith should be placed in line with the formation of opinions and other political aspirations. Functional differentiation in modern society that leads to the individualization of religion does not necessarily imply a loss of influence and relevance of faith in the public sphere. However, of course, religious involvement in the public sphere still has restrictions; namely, the particular religious language of religion must be "translated" first into a style that is acceptable to the public, which has an "epistemic status" that can be accepted by other citizens. ${ }^{43}$

Between religious citizens and secular citizens in a post-secular society can learn from one another. Moreover, citizens of faith are encouraged to wear post-metaphysical ways of thinking (episteme) in religious plurality. Citizens of faith must also learn from science and technology that have the validity claims of

\footnotetext{
40 Ulinnuha.

${ }^{41}$ Ulinnuha.

42 Yonky Karman, “Abraham Inklusif: Sebuah Titik
} Temu Trialog Agama-agama Abrahamik," Jurnal Jaffray 17, no. 2 (September 30, 2019): 185-202, https://doi.org/10.25278/jj.v17i2.321.

${ }^{43}$ Noor, "Identitas Agama, Ruang Publik Dan PostSekularisme: Perspektif Diskursus Jurgen Habermas." 
science. Citizens of religion must also submit to and recognize the secular ratios which form the basis of the legitimacy of the democratic rule of law. ${ }^{44}$

Religious harmony that has been embedded in spiritual life in Indonesia is maintained by increasing religious tolerance in the public sphere, especially in social media. Because through social media, multicultural society tends to experience changes in mindset, attitudes, and even actions. Therefore, it creates peace and seeks peace-loving public spheres and differences in unity that are framed with the same goal.

The public sphere for religion is used to build faith in God. Together, they formulate the meaning of tolerance in religious life in different beliefs, along with realizing an inclusive interfaith dialogue with the aim of friendship and together building a desire to unite to form a unity in diversity.

The religious public sphere is not used as a place to insult other religions. Nor does it use religion as politics, and the reasons for the utterance of hatred. But use the public sphere for peace because all faiths teach it, and long for peace in one nation and state.

\section{Role of Public Sphere in Culture}

The public sphere influences cultural change. The change of music and theater towards commodities shows public criticism of art, which during that period was dominated by certain groups. Furthermore, the difference in the direction of this commodity shows the public's awareness of the equal rights that can place music and theater as public property and not as a tool of social stratification. The change in written culture into a commodity.

On the other hand, shows a different character. If music and theater develop into commodities as a form of class resistance to rights and freedoms, written culture itself becomes a commodity because of purely capitalist

\footnotetext{
${ }^{44}$ Habermas, Between Naturalism and Religion.
}

interests. Press managers at that time began to realize that they have a considerable public, and the function of the press as a communication sphere was directed at the formation of discussion themes that could be followed by all groups. Eventually, the structure of these themes became a vast market potential. ${ }^{45}$

The public sphere can influence the culture of a nation. Radicalism tries to destroy the culture of a society that loves peace and unity. The nation's awakening is controlled by the tight cultural order and discourse ethics that develop through public spheres formed by multicultural communities.

Cultural encounters with religion can be realized in family life and cooperation. Sukri, in his paper, argues culture as a medium to develop the cultural and ethnic identity of the Bugis was mostly denied at the early encounter of Christianity with the indigenous people in South Sulawesi. ${ }^{46}$ Bugis and Makassar culture and Islamic religion can realize good morals based on their learning. ${ }^{47}$ Until now, harmony has been maintained, and it is proven that the cities in South Sulawesi remain safe and prosperous. In addition to Bugis and Makassar culture, Toraja culture in public spaces such as the Rambu Solo ceremony, which can cause conflict, can also be prevented with a high awareness of culture. ${ }^{48}$ Therefore, the encounter between culture and religion in the public sphere can bring about unity and peace.

The public sphere is not only inhabited by one tribe or one culture. The Multicultural public

45 Yadi Supriadi, "Relasi Ruang Publik Dan Pers Menurut Habermas," n.d., 20.

46 Armin Sukri Kanna, "The Implementation of Incarnational Mission Among the Bugis Using Cultural Approach," Jurnal Jaffray 12, no. 1 (April 1, 2014): 93-127, https://doi.org/10.25278/jj71.v12i1.34.

47 Abu Hamid, "Semangat Islam Dalam Kebudayaan Orang Bugis-Makassar," Jurnal Jaffray 4, no. 1 June 1, 2006): 16-24, https://doi.org/10.25278/ji71.v4i1.129.

48 Robi Panggarra, "Konflik Kebudayaan Menurut Teori Lewis Alfred Coser Dan Relevansinya Dalam Upacara Pemakaman (Rambu Solo') Di Tana Toraja," Jurnal Jaffray 12, no. 2 (October 1, 2014): 291-316, https://doi.org/10.25278/jj71.v12i2.20. 
sphere provides a variety of colors that can share different experiences and know other cultures. Finally, the public sphere can be a means of communication to realize shared goals for all cultures.

A public sphere that can gather differences over different cultures can create brotherhood and unity. When conflicts occur, differences can be united through these public spheres. The public sphere should not be exclusive to certain cultures but be inclusive of all cultures. The public sphere becomes open for all cultures to be able to recognize one another's cultures. Indonesia is rich in national power and is united with the motto of Bbinneka Tunggal Ika.

\section{E. Role of Public Sphere in Education}

In the field of Education, public space is manifested in classrooms ranging from an early age to adulthood. The peace education model is a model for realizing classroom culture that creates a peaceful atmosphere. Budiarti argues peace education needs to be done in three stages: the awareness stage through the contemplative model and problem-posing model; the scene of affection through the integration model and role-playing model; then the implementation stage through the action-reflection model. ${ }^{49}$

Besides classrooms as public spaces also present character education by positively using social media. Social media is used as a public sphere to teach the nation's character. ${ }^{50}$ In Islam, there is a Muhadrah method that can be used to increase students' motivation in class in learning religion, character, and peace. ${ }^{51}$

49 Tirsa Budiarti, "Model-Model Pendidikan Perdamaian Bagi Anak Dalam Konteks Gereja," Jurnal Jaffray 16, no. 1 (March 18, 2018): 55-76, https://doi.org/10.25278/jj71.v16i1.280.

${ }^{50}$ Hengki Wijaya and Arismunandar Arismunandar, "Pengembangan Model Pembelajaran Kooperatif Tipe STAD Berbasis Media Sosial," Jurnal Jaffray 16, no. 2 (October 6, 2018): 175-96, https://doi.org/10.25278/jj71.v16i2.302.

51 Nurmadiah Nurmadiah, Sitti Sakinah, and Helaluddin Helaluddin, 'Enhancing Students' Motivation to Learn Arabic Through Method of Muhadharah," in First
The public sphere for education is open and expanded through social media and the internet. Character education, peace education, and multicultural education can be taught through various educational applications such as teacher's room, classroom, e-learning. The public sphere can also be used to counter radicalism, which damages the social and state order.

The public spheres such as canteens, cafes, campus yards, and classrooms can be a place for discussion, sharing, and finding ideas for the development of intellectual abilities, creativity, collaboration, collaboration, and interpersonal communication between students or students and teachers.

The public sphere in education belongs to all students regardless of the status and position of their parents because learning is for all — both for the rich and those who live.

\section{CONCLUSION}

Jurgen Habermas's view that supports diversity in politics, religion, culture, and education is a form of a nation that implements democracy. In the Indonesian context, public sphere functions to carry out freedom with the same goal for the common good.

At present, the public sphere no longer belongs to the bourgeoisie but belongs to the people. Religious, cultural, political, democratic, and educational activities have used the public sphere to discuss, share, determine attitudes, and conduct for common goals.

The public sphere for the Indonesian multicultural community hopes for ideas that can influence government policies in the name of unity, and the welfare of the diverse Indonesian community but remains one in the frame of Bbinneka Tunggal Ika.

\footnotetext{
International Conference on Culture, Education, Linguistics and Literature, CELL 2019 (Proceedings of First International Conference on Culture, Education, Linguistics and Literature, CELL 2019, 5-6 August, Purwokerto, Central Java, Indonesia, Purwokerto, Central Java, Indonesia: EAI, 2019), https://doi.org/10.4108/eai.5-8-2019.2289818.
} 
The condition of Indonesia in politics and democracy are challenged to use the public sphere as an educational sphere and a role model for multicultural societies. The public sphere is not only to determine the attitude of groups, parties, institutions, but the philosophy of nationalism for the unity of the nation.

Religion, culture, education, and different ideas are not obstacles to creating a peaceful, inclusive, and tolerant public space with the principle of deliberation for consensus and brotherhood.

\section{REFERENCES}

Adiwijaya, Dominique Rio. "Perbandingan antara Etika Jürgen Habermas dan Richard Rorty sebagai Prinsip Dasar Bertindak Manusia." Humaniora 1, no. 2 (October 30, 2010): 205-12.

https://doi.org/10.21512/humaniora.v1i 2.2862 .

Budiarti, Tirsa. "Model-Model Pendidikan Perdamaian Bagi Anak Dalam Konteks Gereja." Jurnal Jaffray 16, no. 1 (March 18, 2018): 55-76.

https://doi.org/10.25278/jij1.v16i1.280.

Ferree, Myra Marx, William A. Gamson, Jürgen

Gerhards, and Dieter Rucht. "Four

Models of the Public Sphere in Modern

Democracies." Theory and Society 31, no. 3 (2002): 289-324.

Gumelar, Fajar, and Hengki Wijaya. "Peran

Gereja Masa Kini Menyikapi Teologi

Pembebasan Gutiérrez." BLA': Jurnal

Teologi Dan Pendidikan Kristen Kontekstual 2, no. 1 (June 24, 2019): 14-26.

https://doi.org/10.34307/b.v2i1.69.

Gunawan, Ketut, and Yohanes Rante.

"Manajemen Konflik Atasi Dampak

Masyarakat Multikultural Di Indonesia."

Jurnal Mitra Ekonomi Dan Manajemen Bisnis 2, no. 2 (2011): 212-24.
Habermas, Jürgen. Between Naturalism and Religion: Philosophical Essays. Cambridge, UK; Malden, MA: Polity Press, 2008. . The Structural Transformation of the Public Sphere: An Inquiry into a Category of Bourgeois Society. 10. print. Studies in Contemporary German Social Thought. Cambridge, Mass: MIT Press, 1999.

. "Three Normative Models Of

Democracy." Constellations 1, no. 1

(December 1994): 1-10.

https://doi.org/10.1111/j.1467-

8675.1994.tb00001.x.

Habermas, Jürgen, and William Rehg. Between

Facts and Norms: Contributions to a Discourse Theory of Law and Democracy. 1 MIT Press paperback ed., 4. printing. Studies in Contemporary German Social Thought. Cambridge, Mass.: MIT Press, 2001.

Hamid, Abu. "Semangat Islam Dalam Kebudayaan Orang Bugis-Makassar.” Jurnal Jaffray 4, no. 1 (June 1, 2006): 1624. https://doi.org/10.25278/jj71.v4i1.129. Helaluddin, Helaluddin, and Hengki Wijaya. Analisis Data Kualitatif: Sebuab Tinjauan Teori \& Praktik. Makassar: Sekolah Tinggi Theologia Jaffray Makassar, 2019.

Kanna, Armin Sukri. "The Implementation of Incarnational Mission Among The Bugis Using Cultural Approach." Jurnal Jaffray 12, no. 1 (April 1, 2014): 93-127. https://doi.org/10.25278/ji71.v12i1.34.

Karman, Yonky. "Abraham Inklusif: Sebuah Titik Temu Trialog Agama-agama Abrahamik." Jurnal Jaffray 17, no. 2 (September 30, 2019): 185-202. https://doi.org/10.25278/jj.v17i2.321.

Kawamura, Koichi. "Consensus and Democracy in Indonesia : Musyawarah-Mufakat Revisited." SSRN Electronic Journal, 2011. https://doi.org/10.2139/ssrn.2280935.

Kristianto, Paulus Eko, and Hengki Wijaya. "Tilikan Politik Dan Hak Asasi Manusia Di Era Globalisasi." Preprint. Open 
Science Framework, November 5, 2019. https://doi.org/10.31219/osf.io/u5rg7.

Laar, Ester van, Alexander J.A.M. van Deursen, Jan A.G.M. van Dijk, and Jos de Haan. "The Relation between 21st-Century Skills and Digital Skills: A Systematic Literature Review." Computers in Human Behavior 72 (July 2017): 577-88. https://doi.org/10.1016/j.chb.2017.03.01 0 .

Ngelow, Zakaria J. "Turut Membina Indonesia Sebagai Rumah Bersama - Peran Gereja Dalam Politik Di Indonesia." Jurnal Jaffray 12, no. 2 (October 2, 2014): 213-34. https://doi.org/10.25278/jij1.v12i2.16.

Noor, Irfan. "Identitas Agama, Ruang Publik

Dan Post-Sekularisme: Perspektif

Diskursus Jurgen Habermas.” Ilmu

Ushuluddin 11, no. 1 (2012): 61-87.

Nurmadiah, Nurmadiah, Sitti Sakinah, and Helaluddin Helaluddin. "Enhancing Students' Motivation to Learn Arabic Through Method of Muhadharah.” In First International Conference on Culture, Education, Linguistics and Literature, CELL 2019. Purwokerto, Central Java, Indonesia: EAI, 2019. https://doi.org/10.4108/eai.5-82019.2289818.

Panggarra, Robi. "Konflik Kebudayaan Menurut

Teori Lewis Alfred Coser Dan

Relevansinya Dalam Upacara Pemakaman (Rambu Solo') Di Tana Toraja." Jurnal Jaffray 12, no. 2 (October 1, 2014): 291316.

https://doi.org/10.25278/jj71.v12i2.20.

Prasetyo, Antonius Galih. "Menuju Demokrasi

Rasional: Melacak Pemikiran Jürgen Habermas Tentang Ruang Publik." Jurnal Ilmu Sosial Dan Ilmu Politik 16, no. 2 (2012): 169-84.

Supartiningsih, Supar. "Etika Diskursus Bagi Masyarakat Multikultural: Sebuah Analisis dalam Perspektif Pemikiran Jürgen Habermas.” Jurnal Filsafat 17, no. 1
(March 22, 2017): 32-59. https://doi.org/10.22146/jf.23231.

Supriadi, Yadi. "Relasi Ruang Publik Dan Pers Menurut Habermas," n.d., 20.

Ulinnuha, Roma. "Islam, Ruang Publik Dan Kerukunan Antar Umat Beragama (Studi Tradisi Ngebag Kolaboratif Di Karangjati Wetan)." Jurnal Sosiologi Agama 9, no. 2 (March 17, 2017): 29. https://doi.org/10.14421/jsa.2015.09202.

Weismann, Ivan Th.J. "Naturalisasi Perbudakan Sebagai Suatu Keadilan.” Jurnal Jaffray 1, no. 1 (January 5, 2005): 29. https://doi.org/10.25278/jij1.v1i1.166.

Wijaya, Hengki, and Arismunandar Arismunandar. "Pengembangan Model Pembelajaran Kooperatif Tipe STAD Berbasis Media Sosial." Jurnal Jaffray 16, no. 2 (October 6, 2018): 175-96. https://doi.org/10.25278/ji 71.v16i2.302.

Zaluchu, Sonny, Stephanus Karnadhi, Fransiskus Widjaja, and Harls Siahaan. "Legitimation of Religious Symbols in Politics:

Descriptive Analysis of The Narration of Indonesian Election Campaign 2019.”

Atlantis Press, 2019. https://www.atlantispress.com/proceedings/icdesa19/125923250. 